\title{
Nutritive Value of Vegetable Proteins and its Enhancement by Admixture
}

\author{
By HARRIETTE CHICK*, Lister Institute of Preventive Medicine, \\ London, S.W. I
}

\section{Introduction}

It is only since the beginning of the present century that different proteins have been accredited with different nutritive values. Previously, the proteins in a diet represented purely the necessary nitrogenous fraction, and were 'proteins' and nothing more. The conception of differing 'biological values' possessed by different proteins was founded on the experimental work of Max Rubner and his assistant Karl Thomas (1909). Their investigations and later those of Mitchell (1923-4) showed the differences existing in the amounts of different proteins which were required to maintain an adult human subject or animal in nitrogenous equilibrium or to support the growth of a young animal. The support of growth in the growing organisms is a more searching test for the nutritive value of a protein than the maintenance of an adult, and this criterion was adopted by Osborne and Mendel in their long series of investigations. (See Osborne, Mendel \& Ferry, 1919). By their method the relative nutritive values of different proteins were measured by the weight increase of the experimental animal, usually the young rat, corresponding to the ingestion of a given amount of a protein, which provided the sole source of nitrogen in the diet. The different diets compared contained the same proportion of protein, which was less than the optimum amount in an otherwise complete ration and was thus the factor limiting growth. The ratio, $\frac{\text { g. weight increase }}{\text { g. protein ingested }}$, known as the P.E.R. or 'protein-efficiency ratio', has proved to be a useful measure of nutritive value.

A new approach has been developed from the knowledge of the chemical composition of proteins. As Osborne \& Mendel (1914) said: 'The question of protein synthesis has now become a problem of the biochemical deportment of amino-acids.' Differences in nutritive worth have been found to correspond to differences in the amounts and relative proportions of the different amino-acids which they contain (see Mitchell \& Hamilton, 1929), and the differences are particularly important as regards those aminoacids that are not synthesized in the animal organism, but must be supplied in the dietary proteins (Rose, 1938).

There are advantages and disadvantages in all the methods mentioned above for studying the nutritive efficiency of proteins (Chick, 1947) but, in general, the results obtained by the different methods have shown a satisfactory degree of concordance (Block \& Mitchell, 1946-7).

Proteins of animal origin generally contain a more satisfactory mixture of aminoacids than those contained in vegetables, which are usually relatively poor in tryptophan

- Present address: Uppercross, 34 Storey's Way, Cambridge. 
and lysine, amino-acids essential for support of the growing animal. In a mixed diet, however, great advantage can be secured by an appropriate mixture of proteins from different foods, whereby a deficiency of an essential amino-acid in one may be corrected by an excess in another. This complementary action exists between many animal and vegetable proteins, and is well illustrated by the observation that mixtures of animal proteins from meat or milk with those from cereals have shown a growthsupporting ability not inferior to that of animal protein alone (see McCollum, OrentKeiles \& Day, I939; Hoagland \& Snider, I927; Mitchell \& Carman, 1926). The reason is obvious. Cereals are well supplied with most of the essential amino-acids, but are deficient in the essential amino-acid, lysine, which is relatively abundant in the proteins of meat or milk.

\section{Examples of enhancement by admixture of the nutritive value of vegetable proteins}

Beef tea and toast. An interesting example of such a complementary effect came under observation in the Division of Nutrition of the Lister Institute during a series of tests on the capacity of the proteins of some common foods to support the growth of weanling rats. The hot aqueous extract known as beef tea, from which the solid matter had been removed, was formerly recommended as a nourishing food for invalids and convalescents. In later years, however, it fell into disrepute, wellinformed opinion arguing that all nourishment had been removed with the coagulated material and that the resulting beef tea was no more than a pleasant and stimulating drink. In experiments with weanling rats, fed on a ration in which the nitrogen was provided from beef tea, no weight increase occurred, even when the nitrogen was present to the extent of $3.6 \%$ (20\% 'crude protein') in the diet. When, however, in a diet containing only $2 \cdot 2 \%$ nitrogen, one-quarter was supplied by the beef tea and the remainder by white flour, steady growth occurred and at a rate greater than when white flour alone supplied all the nitrogen (Chick \& Slack, I945). The effect was easily explained. About $70 \%$ of the nitrogen in the beef tea was in the form of gelatine, an imperfect protein lacking both tryptophan and cystine, both of which are present in satisfactory amount in wheat proteins. Gelatine, on the other hand, is rich in lysine, an amino-acid in which cereal proteins are notably deficient. This sparing action for protein is a well-known attribute of gelatine (see Lusk, I928). Jellies and beef tea, taken with a little toast or bread and butter, can, therefore, be safely trusted to provide convalescents with a pleasant and nourishing snack.

Wheat fractions. Complementary action can be demonstrated also between the different vegetable proteins contained in different foods and sometimes in the same food. An example of the latter is the relation between the proteins contained in the outer layers (bran) and the inner portions (endosperm) of the wheat grain. A diet in which the protein was derived in equal amounts from the bran and endosperm of the same sample of wheat was found to maintain growth at a rate exceeding that which occurred on diets supplying an equal proportion of protein from either the bran or the white flour alone (Chick, Cutting, Martin \& Slack, 1947). The supplementary action in this case is explained partly by the fact that the proteins of bran are richer in 
tryptophan and lysine than those of white flour (Jones \& Gersdorff, 1923-4, 1925; Barton-Wright \& Moran, 1946), but what the special contribution of the endosperm proteins may be is at present unknown.

Potato protein and non-protein nitrogen fraction. Another example of a complementary action between different nitrogenous materials in a single food is found in the potato. In this tuber the non-protein nitrogen, which amounts to about half the total, has a marked supplementary effect for the potato protein (tuberin). With diets of comparable nitrogen content, better growth was obtained when it was supplied by the whole tuber than when derived from the purified potato protein (Chick \& Slack, 1949). The non-protein fraction, as contained in potato sap from which the protein had been separated by heat coagulation, was incapable of promoting any weight increase in the experimental animals, but was found to have a markedly stimulating action when combined with wheat gluten, a protein which has the lowest nutritive value of the mixture of proteins present in wheat. With a diet containing $20 \%$ gluten (on dry weight) as source of protein, the average weight increase of weanling rats was $6.5 \mathrm{~g}$. weekly over a period of 7 weeks. When one-quarter of the gluten was replaced by an equivalent amount of nitrogen from the non-protein nitrogenous fraction of potato sap, the growth rate was nearly doubled, to an average weight increase of $11.5 \mathrm{~g}$. weekly. In this instance no explanation has been found in terms of amino-acid supplementation. Only about one-fifth of the non-protein nitrogen of the potato consists of amino-acid nitrogen, and analyses of this fraction have not shown an excess of any essential amino-acid that might so greatly improve the nutritive value of wheat gluten (Slack, 1948).

Cereals and soya-bean meal. Perhaps the most impressive instance of supplementation between vegetable proteins is shown by mixtures of cereal proteins with those of the soya bean, where the mutual advantage gained is great enough to produce a nutritive value comparable with that of milk proteins. In experiments with young rats on diets containing about $10 \%$ of protein derived from white wheat flour or soya flour or milk, the figures for the protein-efficiency ratio were found to be, respectively, $0.83,2.14$ and $2 \cdot 84$. When, however, the $10 \%$ of protein was supplied by a mixture of soya and white flour proteins in equal amount the protein-efficiency ratio was about $2 \cdot 0$ and about equal to that corresponding to a similar mixture of soya and milk proteins (Hove, Carpenter \& Harrel, 1945; see also Jones \& Divine, 1944).

A preparation of soya flour and malted cereals was produced by Caprino in Rome in 1944 and found to be an acceptable food for young children at a time of great milk scarcity. In the expectation that such foods might find useful application in Central Europe in the period following the recent war, the Division of Nutrition of the Lister Institute acceded to the request of the relief organization of U.N.R.R.A. to make an experimental study of such foods. To our surprise we found that a diet containing a mixture of soya flour, malt extract and white flour, in which these ingredients supplied, respectively, 56,34 and $10 \%$ of the total protein, was about equal in growth-supporting value to a diet in which the same amount of total protein was provided entirely from milk (Chick \& Slack, 1946). Following this result, similar combinations of soya and cereals have received extensive trials in Germany since the end of the war, which are 
described by Dean (1949, I95 I). The particular value of soya in these combinations lies in the unusually high proportion of lysine contained in its proteins. Its presence can make good the deficiency of this important amino-acid in the proteins of the cereals and in most other vegetable proteins that have been investigated. When the results of trustworthy analyses are available of the proteins of other legumes and of root and other vegetables, sources may be found of proteins as rich in lysine as those of soya. At present we seem to be dependent on some admixture of soya in any attempt to produce a food of high nutritive value from vegetable products alone.

\section{The animal protein factor}

It would appear, therefore, judged by the practicability of providing a satisfactory supply of essential amino-acids, that it is possible to replace animal proteins in a human diet by an appropriate combination of vegetable proteins. On these grounds alone, there would seem to be no scientific basis for the conviction, widely held, that a certain proportion of animal protein is necessary in a human diet, a conviction which will be strengthened by the evidence Dr Wills has collected in her work among undernourished young children in tropical and sub-tropical countries (Wills, I95 I).

The question, however, arises whether the need for animal protein may not, in fact, be the need for some special nutrient, some animal protein factor, not itself of a protein or amino-acid nature, which is usually found to accompany the protein in animal foods.

Cary and co-workers described experiments in which young rats receiving a diet containing $25 \%$ protein ( $5 \%$ from yeast and $20 \%$ from casein) failed to grow normally if the casein had been purified by successive extractions with hot alcohol (Cary, Hartman, Dryden \& Likely, I946; Hartman, 1946). Normal growth was, however, secured by addition of various animal foods or of a small amount of liver extract, but the necessary factor was not present in yeast, or in the cereals, legumes and root vegetables investigated. The essential nutrient in liver extract was later found to be identical with the anti-pernicious-anaemia principle now known as vitamin $B_{12}$ (Hartman, Dryden \& Cary, 1949).

The presence in the ration of a source of vitamin $B_{12}$ also has been found essential for satisfactory nutrition of poultry and hatching of their eggs (Ott, Rickes \& Wood, I948; see also Stokstad \& Jukes, 1949; Snell \& Wright, 1950).

Vitamin $B_{12}$, now regarded as identical with an essential 'animal protein factor', is known to be capable of storage in the animal organism, and it is probable that mothers that have been fed on a generous mixed diet may transmit substantial reserves to their offspring. It is significant that, in order to demonstrate the need of weanling rats for this nutrient, Cary and his colleagues found it necessary to deprive the mothers during the period of lactation. In the experiments described above, with weanling rats fed on diets containing combinations of vegetable proteins, the mothers had received an excellent mixed diet up to the time of weaning their young, and the fact may explain the lack of evidence in these tests that the young animals had need of any 'animal protein factor' in their ration. 
Whether the previous diet of the human mother may influence the capacity of the human baby to subsist on a purely vegetable diet for a given period after weaning is a point of interest worthy of study.

\title{
REFERENCES
}

Barton-Wright, E. C. \& Moran, T. (1946). Analyst, 71, 278.

Block, R. J. \& Mitchell, H. H. (1946-7). Nutr. Abstr. Rev. 16, 249.

Cary, C. A., Hartman , A. M., Dryden, L. P. \& Likely, G. D. (1946). Fed. Proc. $5,128$.

Chick, H. (1947). Chem. Ef Ind. p. 318.

Chick, H., Cutting, M. E. M., Martin, C. J. \& Slack, E. B. (1947). Brit. F. Nutrit. 1, 161.

Chick, H. \& Slack, E. B. (1945). Biochem. F. 39, xxii.

Chick, H. \& Slack, E. B. (1946). Lancet, 251, 601.

Chick, H. \& Slack, E. B. (1949). Biochem. F. 45, 211.

Dean, R. F. A. (1949). Mschr. Kinderheilk. 97,471 .

Dean, R. F. A. (195I). Brit. F. Nutrit. 5, 269.

Hartman, A. M. (1 946). Fed. Proc. 5, 137.

Hartman, A. M., Dryden, L. P. \& Cary, C. A. (1949). Arch. Biochem. 23, 165.

Hoagland, R. \& Snider, G. G. (1927). F. agric. Res. 34, 297.

Hove, E. I., Carpenter, L. E. \& Harrel, C. G. (1945). Cereal Chem. 22, 287.

Jones, D. B. \& Divine, J. P. (1944). F. Nutrit. 28, 41.

Jones, D. B. \& Gersdorf, C. E. F. (1923-4). F. biol. Chem. 58, i 17.

Jones, D. B. \& Gersdorf, C. E. F. (1925). F. biol. Chem. 64, 241.

Lusk, G. (1928). The Elements of the Science of Nutrition, 4th ed. Philadelphia: W. B. Saunders Co.

McCollum, E. V., Orent-Keiles, E. \& Day, H. G. (1939). The Newer Knowledge of Nutrition, $5^{\text {th }}$ ed. New York: The Macmillan Co.

Mitchell, H. H. (1923-4). F. biol. Chem. 58, 873 .

Mitchell, H. H. \& Carman, G. G. (1926). F. biol. Chem. 68, 183 .

Mitchell, H. H. \& Hamilton, T. S. (1929). The Biochemistry of the Amino Acids. American Chemical Society Monograph Series. New York: Chemical Catalog Co., Inc.

Osborne, T. B. \& Mendel, L. B. (1914). F. biol. Chem. 17, 325.

Osborne, T. B., Mendel, L. B. \& Ferry, E. L. (1919). Y. biol. Chem. 37, 223.

Ott, W. H., Rickes, E. L. \& Wood, T. R. (I948). F. biol. Chem. 174, 1047.

Rose, W. C. (1938). Physiol. Rev. 18, 109.

Slack, E. B. (1948). Nature, Lond., 16r, 2 II.

Snell, E. E. \& Wright, L. D. (1950). Ann. Rev. Biochem. 19, 277.

Stokstad, E. L. R. \& Jukes, T. H. (1949). Ann. Rev. Biochem. 18, 435.

Thomas, K. (1909). Arch. Anat. Physiol., Lpz., Physiol. Abt. p. 2 I9.

Wills, L. (195I). Brit. Y. Nutrit. 5, 265.

- Given in original as Gartman, obvious misprint,

\section{The Glinical Picture in Children Fed after Weaning on a Predominantly Vegetable Diet}

\author{
By LUCY WILLS, late of McCord's Zulu Hospital, Durban, \\ and the Royal Free Hospital, London
}

\section{Introduction}

The clinical findings in infants and children fed after weaning on predominantly vegetable diets is the subject of this paper; my experience has been chiefly with the African, so most of the space will be devoted to a description of the syndrome of malignant malnutrition, kwashiorkor, or fatty liver disease of infants as Waterlow calls it, as seen in the Bantu race. It must be understood that this syndrome, which I take to be the extreme expression of the ill-effects of such diets, is not limited to the African; it is seen in all races, and Czerny's 'Mehlnährschaden' is probably the same condition in European children. 